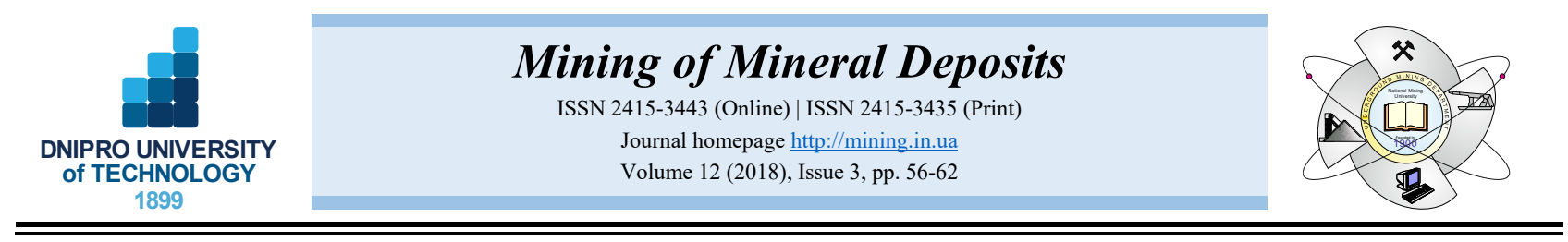

UDC 622.24 .053

https://doi.org/10.15407/mining12.03.056

\title{
USE OF THE ENERGY OF PARAMETRIC OSCILLATIONS TO IMPROVE DRILLING INDICES
}

\author{
V. Svitlytskyi ${ }^{1}$, P. Ohorodnikov², Yu. Kovalchuk ${ }^{3 *}$ \\ ${ }^{\prime}$ Odessa National Academy of Food Technologies, Odessa, Ukraine \\ ${ }^{2}$ International Scientific-Technical University named after Academician Yuri Bugay, Kyiv, Ukraine \\ ${ }^{3}$ Kyiv National University of Construction and Architecture, Kyiv, Ukraine \\ *Corresponding author: e-mail juliakovalchuk25@gmail.com,tel.+380661937088
}

\begin{abstract}
Purpose. Increase of the efficiency of using energy of parametric oscillations within the assembly of drilling string bottom by means of solving nonlinear-parametric equations of a "bit - drive motor - drilled-out rock" system to improve drilling indices.

Methods. The paper applies the method of mathematical modeling of a mechanical system as well as impedance method to study oscillations. While modeling the system, a bit is considered to be an absolutely solid body; elastic elements are non-inertial, drive motor is ideal, and resistance in elastic relations is viscous. While modeling dynamic parameters of a drill string and its interaction with a near-bit system and bottom hole, mechanical system is represented in the form of blocks interacting with each other. Drill string in models is a sequential system of uniform rods.

Findings. In the course of analytical studies, it has been proved that use of energy of parametric oscillations within the assembly of drilling string bottom makes it possible to increase axial load on a bit as well as rise mechanical velocity especially while drilling horizontal areas of inclined boreholes. Dynamic parameters of mechanical system of a drill string and its interaction with near-bit system and bottom hole have been substantiated. It has been determined that limitation of the amplitude of resonant vertical oscillations for a bit is possible at the expense of toothed surface of cone rollers in terms of periodical positioning from one tooth to two teeth, physical and mechanical properties of the drilled-out rocks, and features of correcting elements mounted above the bit.
\end{abstract}

Originality. Innovative mathematical model describing dynamics of the operation of a "bit - drive motor - drilledout rock" mechanical system has been developed taking into consideration the effect of parametric oscillations.

Practical implications. Limited amplitude of resonant vertical oscillations of a bit is the condition of efficient assembly operation and long service life of its components in the context of parametric excitations. The obtained results may be useful while designing drill rigs.

Keywords: drill string, bit, borehole, bottom hole motor, screw motor, load, turbobit

\section{INTRODUCTION}

Drilling is one of the most costly and risky activities in the field of prospecting and development of oil and gas deposits. To some extent, that high cost is connected with the extraneous vibrations while drilling. Along with the development of various devices to measure data in the process of drilling and to implement them in real time, vibration models are still a valuable tool to analyze random drilling as well as to design and study sensitivity of the input parameters. Recently, wide range of models has been developed to design and analyze drilling rigs. Owing to the complexity of well operation and excitation, certain model simplifications and assumptions take place.
Scientific literature demonstrates thorough studies on modeling vibrations while drilling. Author of paper (Heisig, Sancho, \& Macpherson, 1998) describes borehole facilities equipped with various dynamics sensors, and high-speed data-collection system and dataprocessing algorithm which helps control vibrations continuously; further, that makes it possible to control drilling process at a new level. In his paper (Gibbs, 1975) the author considers a situation with modern models to predict axial, rotary, and bending oscillations (connected and disconnected), assumptions of boundary conditions, methods to formulate equations and use them to relieve vibrations. Authors of papers (Chernin, Vilnay, \& Shufrin, 2016; Eren \& Kok, 2018; Khajiyeva, Kudaiber-

(C) 2018. V. Svitlytskyi, P. Ohorodnikov, Yu. Kovalchuk. Published by the Dnipro University of Technology on behalf of Mining of Mineral Deposits. This is an Open Access article distributed under the terms of the Creative Commons Attribution License (http://creativecommons.org/licenses/by/4.0/), which permits unrestricted reuse, distribution, and reproduction in any medium, provided the original work is properly cited. 
genov, \& Kudaibergenov, 2018) discuss drilling problems concerning vibration modeling in the context of the available drilling techniques, such as drilling deflection and use of vibration borehole tools. Paper (Parsian, Magnevall, Beno, \& Eynian, 2014) considers torsion-axial engagement; the author proposes model of time domain to model vibration oscillations. The obtained model is a system of differential equations. Set of experiments to test the model is represented as well. Different strategies to solve the vibration problems are studied with the discussion of their possibility to be used while drilling.

Development and application of the drill-string bottom design while drilling by various techniques is connected with the necessity of performing preliminary dynamic analysis of the structure taking into consideration nonlinear and parametric characteristics of elastic and dissipative coupling, drive power, and peculiarities of interaction between the process duties and a rockbreaking tool (bit) (Saroyan, 1979; Ogorodnikov, 1991; Yunin \& Khegay, 2004).

Nowadays, the amount of papers containing results of calculation of drill string dynamics taking into consideration effect of parametric oscillations is rather limited (Bakenov, Gabler, Detournay, \& Germay, 2003; Ghasemloonia, Geoff Rideout, \& Butt, 2014; Saldivar, Mondié, Niculescu, Mounier, \& Boussaada, 2016). Paper (Ghasemloonia, Geoff Rideout, \& Butt, 2014) gives dynamic model of the whole drill string of oil wells with several stabilizers for bottom-hole assembly. Effect of axial vibration generator in a drill string is studied. Moreover, the paper models connected nonlinear axialtransverse dynamics of the whole drill string and analyses qualitatively the lateral instabilities. Paper (Saldivar, Mondié, Niculescu, Mounier, \& Boussaada, 2016) represents overview of the modeling of axial and torsional self-directing drilling vibrations. Paper (Bakenov, Gabler, Detournay, \& Germay, 2003) studies vibrations while drilling. The paper shows possibility to control vibration modes and improve drilling indices. Review of the literature makes it possible to state that today the evaluation of the efficiency of using the parametric oscillations to improve drilling indices requires more detailed studies. According to modern ideas and analysis of the designs of drill string layout, it is clear that in most cases their mechanical part may be represented in the form of one or set of spring rods connected with each other and with the bottom in elastic and dissipative way. The rods may perform rotary, longitudinal, bending, longitudinalbending, and parametric oscillations.

While studying oscillation processes, one should take into account nonlinearity of the properties of the drilledout rock. Paper (Depouhon \& Detournay, 2014) analyzes stability of a discrete model to study self-excited axial and torsional oscillations of deep drilling systems. The obtained data are illustrated in terms of deep drilling; it is shown that they correspond to the tendencies observed in drilling. Paper (Ghasemloonia, Geoff Rideout, \& Butt, 2015) gives extensive overview of the literature concerning modeling of drill string vibrations. Besides, it discusses certain problems of drill string vibration modeling in terms of the available drilling techniques and the use of vibration borehole tools. Review paper (Patil \& Teo- doriu, 2013) generalizes the research carried out in the sphere of modeling and control of rotary oscillations. The represented experimental studies are carried out in laboratories to simulate vibration oscillations.

The idea of a drill string as a determined system is somehow idealized. It is known that random and parametric oscillations may occur even within the systems with determined parameters (Ogorodnikov, 1991; Depouhon \& Detournay, 2014; Ghasemloonia, Geoff Rideout, \& Butt, 2014). Basing upon that, it is especially important to take into account certain changes in physical and mechanical parameters of the drilled-out rocks, exciting force, and dissipative forces of elastic relations. While developing design of the drilling rig bottom with a correcting device in the form of parametric oscillation generator, it is rather hard to provide purely parametric excitation; that is why, it is accompanied by simple force excitation. Thus, it is required to take into consideration both parametric and force or kinematic excitation.

Asynchronous electric motors, turbodrills, propeller engines, and bit drive in the form of a drill string driven from the external drive - rotor - are usually used as a bit drive.

Efficiency of rock breaking on the bottom hole depends upon the selected drilling modes, stable bottomhole cleaning, rock properties, and dynamic loads transferred to a bit from dynamically excited components of a drill string (Ghasemloonia, Geoff Rideout, \& Butt, 2014). Nowadays, among the available techniques to excite oscillation processes within the drill string components as a mechanical system, i.e. force, kinematic, autooscillation, and parametric, only the latter has not been considered properly yet being not used to improve intensity of bit-bottom hole interaction (Tsifanskiy, Bersnevich, \& Oke, 1991). There may be several reasons for that. The main reason may be as follows: studies of the drill string dynamics as a mechanical system with parametric excitation are connected with certain difficulties of solving nonlinearly parametric differential equations. Moreover, structural solutions providing time changes of one of energy parameters (rigidity and mass) have not been developed yet.

It is of special importance to take into consideration interaction of a bit with the bottom-hole rock according to deformational, hysteretic, and stochastic properties of the rocks being drilled out in terms of the available parametric excitation. Correspondingly, objective of the paper is to prove the efficiency of using the energy of parametric oscillations within the layout of the drill string bottom to improve drilling indices.

\section{METHODS}

"Cone bit - drive motor-drilled-out rock" system is described by a complex system of nonlinear-parametric equations which include different-type nonlinear functions. Task of the studies also involves solution of such a system of equations which will describe drill string dynamics taking into consideration parametric excitations.

The study applies methods of mathematical and physical modeling, i.e. impedance method of oscillation studies (Vul'fson \& Kolovskiy, 1969). While developing mathematical model, a set of assumption is taken into account. Bit is considered to be an absolutely solid body; 
elastic elements are non-inertial, drive motor is ideal, and resistance in elastic relations is viscous. To analyze dynamic parameters of a mechanical system of a drill string and its interaction with a near-bit system and bottom hole, mechanical system is represented in the form of blocks interacting with each other.

Drill string in models is a sequential system of uniform rods. In the context of repetition of a calculation stage while transferring along the drill string sections, it is possible to use generalized block of the model being a combination of lumped and shared elements.

\section{RESULTS AND DISCUSSION}

\subsection{Description of a device to generate parametric oscillations}

First, consider the structure (Fig. 1) of a correcting device which generates parametric oscillations. The device consists of upper adapter 1 , connected to a body with threading 2 where there is a set of spring plates 3 being firmly connected (mounted) into the adapter 1 . Another set of spring plates 4 with other geometrical and elastic parameters is mounted through a stiff coupling 8 ; lower parts of the plates are tightly connected to a multiple-thread screw 6 .

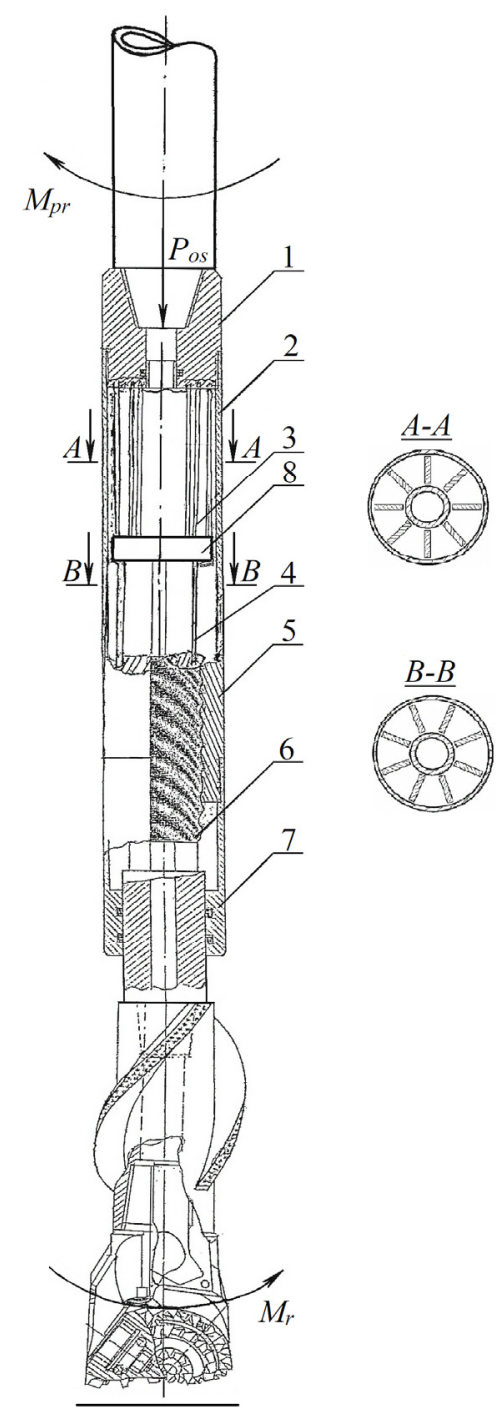

Figure 1. Correcting device to generate parametric oscillations
Screw 6 interacts with a multiple-thread nut 5 which is fixed threadedly to the body 2 , and studding box 7 is fixed threadedly to a nut 5 . Lack screw and cone bit are fixed to the end of a screw 6 . A tube for flushing liquid goes through the center of the device. The device operates (Fig. 1) as follows: drive shaft of the bottom-hole motor or a drill string is connected to a shaft 2 through the adapter 1 ; the shaft is made of coaxial parts and flat band springs 3 and 4 firmly fixed between them; the springs are mounted perpendicularly to each other along the shaft axis. During rotation of a drill string or drive shaft of a bottom-hole motor, stiffness of structure 2, 3, and 4 changes periodically towards the support springs; owing to that fact, parametric oscillations of a bit are excited.

\subsection{Mathematical representation of parametric oscillations of the drill string bottom}

Limited amplitude of vertical oscillations of a bit at the expense of toothed surface of a cone roller (periodical positioning from one tooth to two teeth) and elastic properties of the drilled-out rocks on the bottom hole are the conditions of efficient operation of the assembly and long service life of its components. Note that with an accuracy to small quantities of the second order relative to the coefficient of parametric excitation $\mu$, hardness towards axis $x$ changes according to law:

$k_{p}=(1+\mu \sin \Omega t)$,

where:

$\Omega t$ - the velocity of drive shaft (drill string) rotation.

Taking into account the adopted assumptions, bit motion without consideration of oscillation damping described in equation (2) (Tsifanskiy, Bersnevich, \& Oke, 1991) is:

$$
\begin{aligned}
& m \frac{d^{2} x}{d t^{2}}+b(x) \frac{d x}{d t}+b_{p}\left(1+\mu_{1} \sin \Omega t\right) \frac{d x}{d t}+ \\
& +F_{r}(x)+k_{p}(1+\mu \sin \Omega t) x=0,
\end{aligned}
$$

where:

$b(x)$ - the coefficient which is a function of a model stiffness and movement of the bit center when a bit is positioned from one tooth to two teeth;

$b_{p}$ - the coefficient taking into account excitation of parametric oscillations from the action of nonlinear elastic elements which axes coincide with axis $x$ (both coefficients $(x)$ and $b_{p}$ depend upon the velocity of elements located along axis $x$;

$F_{r}(x)$ - the coefficient depending upon the stiffness of a system, axial movement of the bit center, and coordinate $x$;

$k_{p}$ - the coefficient of stiffness of the device which excites parametric oscillations;

$\mu_{1}$ and $\mu$-coefficients of parametric excitation being proportional to velocity $d x / d t$ and movement along coordinate $x$ respectively (Vul'fson, \& Kolovskiy, 1969).

A drill string consists of the sequence of sections that is the successive mechanical connection of drill and casing pipes which lower part includes a rock-breaking tool. Following lumped elements are taken in the model as simplest ones: mass $M$, flexibility $C$, and general loss resistance $R$, assuming that the force required for their surpassing is proportional to the velocity of movement. Figure 2 represents a drill string model. 
(a)

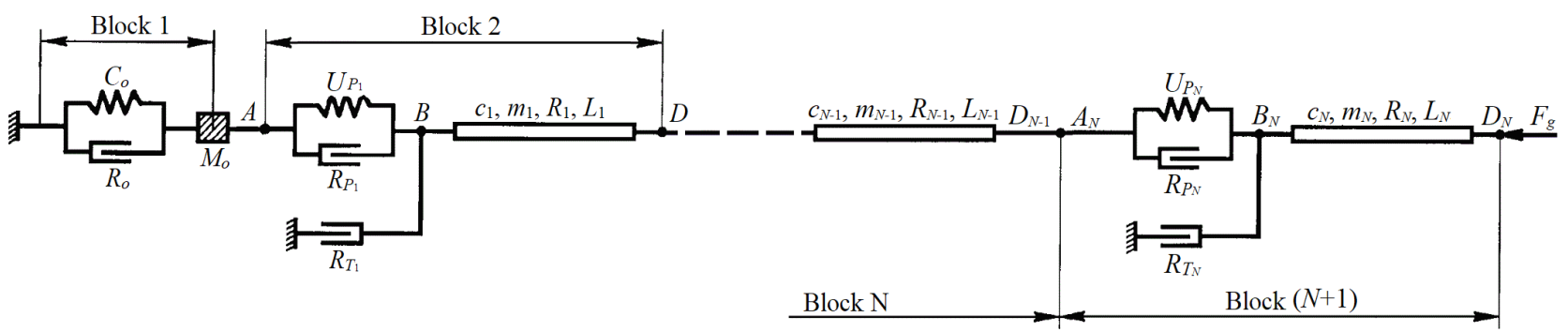

(b)

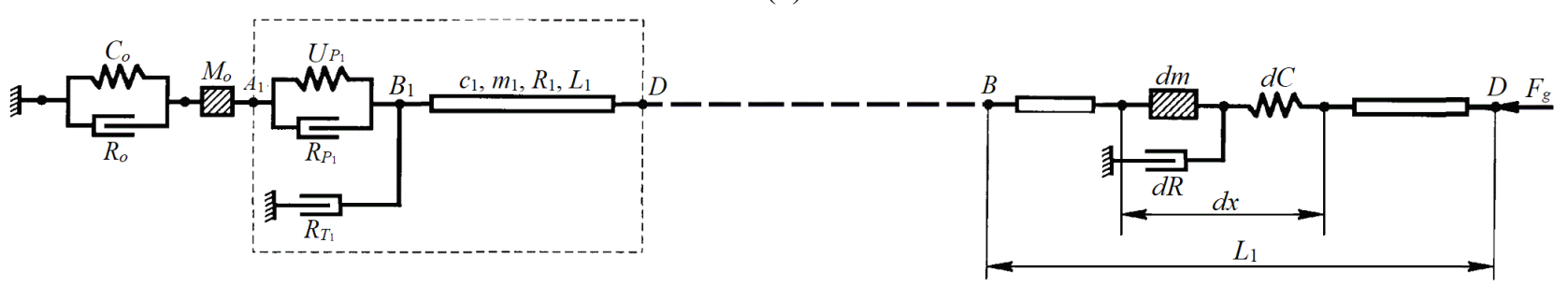

Figure 2. Scheme of a drill string in the form of blocks: (a) a model with the distributed parameters; (b) a model with the lumped parameters

Block one models tackle system with stiffness $C_{0}$ and mass of a movable load $M_{0}$ (Fig. 2a). As a real oscillation system, tackle system has a generalized resistance. Taking into consideration rigid fixing of the stationary part of the block, we obtain nodal connection of three mechanical resistances in our model. Owing to the fact that dynamic load is applied to input $A$ from a drill string, tackle system responses to parallel reactions of all the three elements. Further, to study such a mechanical system, we will use impedance method of oscillation studies (Skuchik, 1971).

According to the rule of addition, impedance at point $A$ is expressed with the help of formula (3):

$Z_{0}=R_{0}+i\left(\omega M_{0}+\frac{1}{\omega C_{0}}\right)=R_{m}+i x_{m}$

where:

$$
\begin{aligned}
& Z_{0} \text { - input impedance of a tackle system; } \\
& \omega-\text { cyclic frequency; } \\
& i=\sqrt{-1} ; R_{m}=R_{0} ; x_{m}=\omega M_{0}+1 / \omega C_{0}
\end{aligned}
$$

Block two of the model includes upper section of drill pipes (Fig. 2b). Within the admissible boundaries of minor area $d x$ of the rod of a uniform section with $L_{i}$ length, distributed parameters may be replaced by the lumped ones (Fig. 2b):

$d m=m_{1} d x ; d C=C_{1} d x ; d R=R_{1} d x$,

where:

$m_{1}$ - the mass of a rod length unit;

$C_{1}$ - the flexibility of a rod length;

$R_{1}$ - the loss resistance per a rod length unit.

Value $R_{1}$ is determined in terms of the characteristics of the processes in a drill string; it is taken as a constant one with some assumptions.

Dimensional analysis demonstrates possibility of calculations according to the known damping coefficient $\beta$ :

$R_{1}=\sqrt{\beta^{2}+\omega m_{1} C_{1} \frac{2 \beta}{\omega C_{0}}}$ i.e., approximate equivalence $R_{1}$ of damping coefficient $\beta$ is observed.

Section $A D$ contains linearized parameters of a damper and concentrated friction at point $B$; section $B D$ contains section of drill pipes in the form of a rod. Excitation from a bit, if the set has no correcting elements (generator of parametric oscillations, damper) is transferred to point $D\left(D_{1}\right)$. Section $O B$ is the load for rod system $B D$. Impedance of sections $A B$ and $O B$ is as follows:

$Z_{A B}=R_{U_{p_{1}}}-\frac{i}{\omega U_{p_{1}}}=R U_{p}+i X_{U_{p}}$

$Z_{B}=\frac{Z_{0} Z_{A B}}{Z_{0}+Z_{A B}}+R_{T_{1}}=\left(R_{B}+R_{T_{1}}\right)+i X_{B}$

where:

$Z_{A B}$ - impedance of section $A B$;

$R_{p}$ - loss resistance in a damper;

$U_{p}$ - linearized flexibility of a damper;

$Z_{B}$ - impedance of section $O B$;

$R_{B}$ - active component of the impedance;

$R_{T 1}$ - is loss resistance on expanders, centralizers etc.;

$X_{B}$ - reactive components of the impedance.

Impedance at the end of rod $D$ is the load for a distributed system of pipes being modeled by rod $B D$ in the considered system. In terms of dynamic excitation $F_{g}$ impedance of the system input at point $B D$ is:

$Z_{D}=w_{0}^{\prime} \operatorname{cth}\left(\gamma L_{1}-\theta\right)$,

where:

$w_{0}^{\prime}-$ wave resistance of a rod taking into consideration loss resistance;

$\gamma-$ a distribution constant;

$L_{1}$ - length of drill pipes;

$\theta$ - phase angle taking into account effect of the terminal load, i.e. discordance of $w_{0}^{\prime}$ and $Z_{D}$.

$w_{0}^{\prime}=\sqrt{\frac{R_{1}+i \omega m_{1}}{i \omega C_{1}}} ;$ 
$\gamma=\sqrt{\left(R_{1}+i \omega m_{1}\right) i \omega C_{1}}$

$\theta=\operatorname{arth}\left(-\frac{w_{0}^{\prime}}{Z_{D}}\right)$.

If there is a second consequent rod, then the value is reassigned to point $A$, and parameters of other rod are introduced into section $A D$ without any changes. Solutions are repeated relative to all the distributed elements. As a result, we obtain impedance of the drill string input:

$Z_{B x}=R_{B x}+i X_{B x}$,

where:
$R_{B x}$ - active component $Z_{B x}$ of a drill string;

$X_{B x}$ - reactive component $Z_{B x}$.

In terms of average value of the amplitude of longitudinal oscillations of bit $H_{d}$, determine amplitude of dynamic load on a bit:

$F_{g}=\left|Z_{B x}\right| \omega H_{d}$.

In the course of frequency study of a model, we obtain dependence of the amplitude of dynamic load as a function of interaction frequency or rotation frequency of a bit and bit-bottom hole interaction, if correcting elements (damper, generator of parametric oscillations) are located above the bit (Fig. 3).

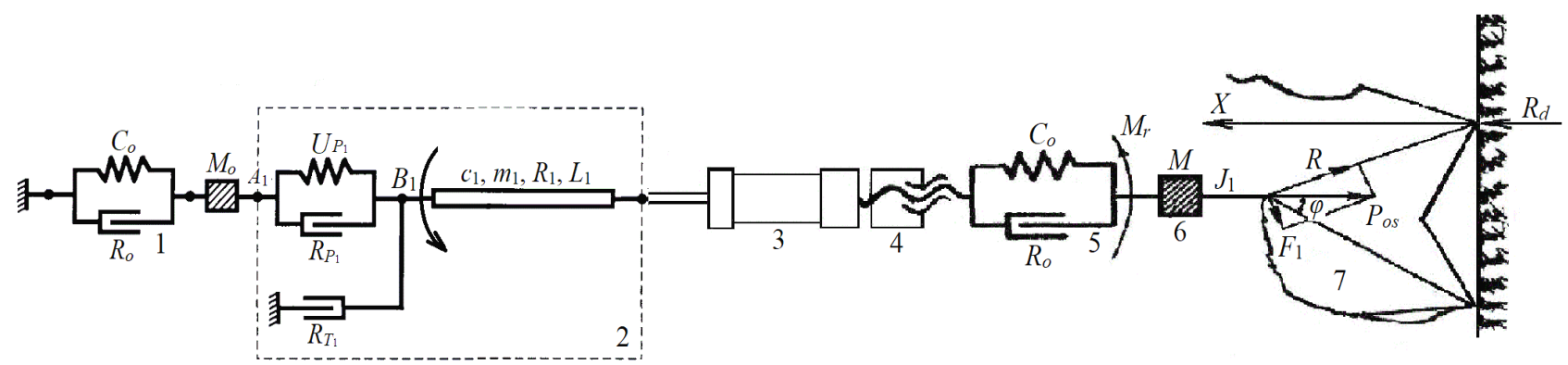

Figure 3. Scheme of roller cone operation taking into consideration correcting elements: 1-tackle system; 2-drill string; 3 - generator of parametric oscillations; 4 -screw pair (screw intensifier of axial load); 5 -damper; 6 -near-bit mass (adapter); and 7-bit; $M_{r}$-moment of resistance; $C_{0}$-damper stiffness; $M$-near-bit mass; $J_{1}$-reduced moment of inertia; $X$-coordinate axis; $R$-interaction force of a roller cone tooth and rock; $\varphi$-turn angle of a roller cone; $F_{1}$-force effecting the axis of a roller cone; $R_{d}$-force of the bottom hole

Basing upon the scheme (Fig. 3.) and expression to determine dynamic load on a bit 9 as well as taking into account changes in its operation at the expense of the effect of correcting elements, we obtain:

$F_{g}=\left|Z_{B x}\right| \omega H_{d} \frac{1}{\tan \gamma} k_{p}(1+\mu \sin \Omega t)$,

where:

$1 / \tan \gamma$ - transmission number of a screw mechanism.

Input energy flow into a drill string of all the blocks is characterized by the conducted power within the active components of input impedance:

$$
W=\frac{0.5 F_{g_{0}} v_{m_{0}} R_{B x}}{\left|Z_{B x}\right|} .
$$

Transmission function $T$ of a drill string is obtained as a ratio of amplitudes of vibrovelocity of movable load (swivel) $v_{m 0}$ and vibrovelocity of bit $\Omega t$. Hence, in terms of the preset amplitude of kinematic excitation on a bit, if there are no correcting elements for a drilling mode, transmission function of a drill string is of the form similar to amplitude-frequency characteristic of oscillations of the upper part of a drill string:

$$
T=\frac{v_{m_{0}}}{\Omega t} \text {. }
$$

That is proved by numerous vibrorecords of oscillations immediately in the process of vertical borehole drilling.

\section{CONCLUSIONS}

Oscillations of "cone bit-drive-drilled-out rock" system are described with the help of a complex system of nonlinear-parametric equations which include diverse nonlinear functions.

Limited amplitude of resonance vertical oscillations of a bit at the expense of toothed (height and geometry of the equipment) surface of periodical relocation from one tooth to two teeth, physical and mechanical properties of the drilled-out rock, and properties of correcting elements mounted above the bit is the conditions of efficient assembly operation and long service life of its components in the context of parametric excitations.

Cone bit is a mechanism with "discontinuous" motion; it is subject to considerable distortion of the output kinematic functions. That disadvantage is connected with intermittent changes in derived functions of the location of an introduced elements (bit) resulting in periodical impulsive excitations.

Drill string consists of a set of sections being a set of blocks which include elements with both lumped and distributed parameters. That makes it possible to use impedance method for its dynamic study and determine its effect upon correcting elements and a bit.

\section{ACKNOWLEDGEMENTS}

The results of the study were obtained without any support from any project or financing. 


\section{REFERENCES}

Bakenov, A.S., Gabler, T., Detournay, E., \& Germay, C. (2003). Enhanced drilling performance through controlled drillstring vibrations. In AADE 2003 National Technology Conference "Practical Solutions for Drilling Challenges" (pp. 1-8). Houston, Texas, United States: Houston Chapter of the American Association of Drilling Engineers.

Chernin, L., Vilnay, M., \& Shufrin, I. (2016). Blast dynamics of beam-columns via analytical approach. International Journal of Mechanical Sciences, (106), 331-345. https://doi.org/10.1016/j.ijmecsci.2015.12.018Chernin

Depouhon, A., \& Detournay, E. (2014). Instability regimes and self-excited vibrations in deep drilling systems. Journal of Sound and Vibration, 333(7), 2019-2039. https://doi.org/10.1016/i.jsv.2013.10.005

Eren, T., \& Kok, M.V. (2018). A new drilling performance benchmarking: ROP indexing methodology. Journal of Petroleum Science and Engineering, (163), 387-398. https://doi.org/10.1016/j.petrol.2018.01.002

Ghasemloonia, A., Geoff Rideout, D., \& Butt, S.D. (2014). Analysis of multi-mode nonlinear coupled axial-transverse drillstring vibration in vibration assisted rotary drilling. Journal of Petroleum Science and Engineering, (116), 36-49. https://doi.org/10.1016/j.petrol.2014.02.014

Ghasemloonia, A., Geoff Rideout, D., \& Butt, S.D. (2015). A review of drillstring vibration modeling and suppression methods. Journal of Petroleum Science and Engineering, (131), 150-164. https://doi.org/10.1016/i.petrol.2015.04.030

Gibbs, S.G. (1975). Computing gearbox torque and motor loading for beam pumping units with consideration of inertia effects. Journal of Petroleum Technology, 27(09), 1153-1159. https://doi.org/10.2118/5149-pa

Heisig, G., Sancho, J., \& Macpherson, J.D. (1998). Downhole diagnosis of drilling dynamics data provides new level drilling process control to driller. SPE Annual Technical Conference and Exhibition, 1-10. https://doi.org/10.2118/49206-ms

Khajiyeva, L., Kudaibergenov, A., \& Kudaibergenov, A. (2018). The effect of gas and fluid flows on nonlinear lateral vibrations of rotating drill strings. Communications in Nonlinear Science and Numerical Simulation, (59), 565-579. https://doi.org/10.1016/j.cnsns.2017.12.008

Ogorodnikov, P.I. (1991). Upravlenie uglubleniem skvazhiny na baze izucheniya dinamicheskikh protsessov $v$ buril'noy kolonne. Dissertatsiya doktora tekhn. nauk. Moskva, Rossiya: MINKh i GP im. ak. I.M. Gubkina.

Parsian, A., Magnevall, M., Beno, T., \& Eynian, M. (2014). A mechanistic approach to model cutting forces in drilling with indexable inserts. Procedia CIRP, (24), 74-79. https://doi.org/10.1016/j.procir.2014.07.138

Patil, P.A., \& Teodoriu, C. (2013). A comparative review of modelling and controlling torsional vibrations and experimentation using laboratory setups. Journal of Petroleum Science and Engineering, (112), 227-238. https://doi.org/10.1016/j.petrol.2013.11.008

Saldivar, B., Mondié, S., Niculescu, S.-I., Mounier, H., \& Boussaada, I. (2016). A control oriented guided tour in oilwell drilling vibration modeling. Annual Reviews in Control, (42), 100-113. https://doi.org/10.1016/j.arcontrol.2016.09.002

Saroyan, A.E. (1979). Buril'nye kolonny v glubokom burenii. Moskva, Rossiya: Nedra.

Skuchik, E. (1971). Prostye i slozhnye kolebatel'nye sistemy. Moskva, Rossiya: Mir.

Tsifanskiy, S.A., Bersnevich, V.I., \& Oke, A.B. (1991). Nelineynye i parametricheskie kolebaniya vibratsionnykh mashin tekhnologicheskogo naznacheniya. Riga, Latviya: Zinatne.

Vul'fson, I.I., \& Kolovskiy, M.Z. (1969). Nelineynye zadachi dinamiki mashin. Leningrad, Rossiya: Mashinostroenie.

Yunin, E.K., \& Khegay, E.K. (2004). Dinamika glubokogo bureniya. Moskva, Rossiya: Nedra.

\section{ВИКОРИСТАННЯ ЕНЕРГІЇ ПАРАМЕТРИЧНИХ КОЛИВАНЬ ДЛЯ ПІДВИЩЕННЯ ПОКАЗНИКІВ БУРІННЯ}

\section{В. Світлицький, П. Огородніков, Ю. Ковальчук}

Мета. Підвищення ефективності використання енергії параметричних коливань у компоновці низу бурильної колони шляхом розв'язання нелінійно-параметричних рівнянь системи “долото - приводний двигун - розбурювана порода" для підвищення показників буріння.

Методика. В роботі використано метод математичного моделювання механічної системи та імпедансний метод дослідження коливань. При моделюванні системи долото вважається абсолютно твердим тілом, пружні елементи - безінерційними, приводний двигун - ідеальним, а опір у пружних зв'язках - в'язким. При дослідженні динамічних параметрів бурильної колони та її взаємодії з наддолотною системою і вибоєм механічна система представлена у вигляді блоків, які взаємодіють поміж собою. Бурильна колона в моделях становить послідовну систему однорідних стрижнів.

Результати. В ході аналітичних досліджень було доведено, що використання енергії параметричних коливань у компоновці низу бурильної колони дає можливість збільшити осьове навантаження на долото та підвищити механічну швидкість, особливо під час буріння горизонтальної частини похило спрямованих свердловин. Обгрунтовано динамічні параметри механічної системи бурильної колони та іï взаємодії з наддолотною системою і вибоєм. Виявлено, що обмеження амплітуди резонансних вертикальних коливань досягається долотом за рахунок зубчатої поверхні шарошок при періодичному переступанні з одного зуба на два, фізико-механічних властивостей розбурюваних порід і властивостей коректуючих елементів, встановлених над долотом.

Наукова новизна. Розроблено нову математичну модель, що описує динаміку роботи механічної системи “долото - приводний двигун - розбурювана порода” з урахуванням впливу параметричних коливань.

Практична значимість. Наявність обмеження амплітуди резонансних вертикальних коливань долота створює умови працездатності компоновок і довговічності іiі елементів із параметричними коливаннями. Отримані результати можуть бути корисними при проектуванні бурових конструкцій.

Ключові слова: бурильна колона, долото, свердловина, вибійний двигун, гвинтовий двигун, навантаження, турбобур 


\section{ИСПОЛЬЗОВАНИЕ ЭНЕРГИИ ПАРАМЕТРИЧЕСКИХ КОЛЕБАНИЙ ДЛЯ ПОВЫШЕНИЯ ПОКАЗАТЕЛЕЙ БУРЕНИЯ}

\section{В. Светлицкий, П. Огородников, Ю. Ковальчук}

Цель. Повышение эффективности использования энергии параметрических колебаний в компоновке низа бурильной колонны путем решения нелинейно-параметрических уравнений системы “долото - приводной двигатель - разбуриваемая порода" для повышения показателей бурения.

Методика. В работе использован метод математического моделирования механической системы и импедансный метод исследования колебаний. При моделировании системы долото считается абсолютно твердым телом, упругие элементы - безинерционными, приводной двигатель - идеальным, а сопротивление в упругих связях - вязким. При исследовании динамических параметров бурильной колонны и ее взаимодействия с наддолотной системой и забоем механическая система представлена в виде блоков, которые взаимодействуют между собой. Бурильная колонна в моделях составляет последовательную систему однородных стержней.

Результаты. В ходе аналитических исследований было доказано, что использование энергии параметрических колебаний в компоновке низа бурильной колонны позволяет увеличить осевую нагрузку на долото и повысить механическую скорость, особенно при бурении горизонтальной части наклонно-направленных скважин. Обоснованы динамические параметры механической системы бурильной колонны и ее взаимодействия с наддолотной системой и забоем. Выявлено, что ограничения амплитуды резонансных вертикальных колебаний достигается долотом за счет зубчатой поверхности шарошек при периодическом перешагивании с одного зуба на два, физико-механических свойств разбуриваемых пород и свойств корректирующих элементов, установленных над долотом.

Научная новизна. Разработано новую математическую модель, описывающую динамику работы механической системы “долото - приводной двигатель - разбуриваемая порода” с учетом влияния параметрических колебаний.

Практическая значимость. Наличие ограничения амплитуды резонансных вертикальных колебаний долота создает условия работоспособности компоновок и долговечности ее элементов с параметрическими колебаниями. Полученные результаты могут быть полезными при проектировании буровых конструкций.

Ключевые слова: бурильная колонна, долото, скважина, забойный двигатель, винтовой двигатель, нагрузка, турбобур

\section{ARTICLE INFO}

Received: 5 March 2018

Accepted: 10 August 2018

Available online: 20 August 2018

\section{ABOUT AUTHORS}

Victor Svitlytskyi, Doctor of Technical Sciences, Professor of the Department of Heat Power Engineering and Pipeline Transport of Energy Carriers, Odessa National Academy of Food Technologies, 112 Kanatna St, 65039, Odessa, Ukraine. E-mail: svetlitsky@i.ua

Petro Ohorodnikov, Doctor of Technical Sciences, Dean of the Faculty of Oil and Gas Engineering, International Scientific-Technical University named after Academician Yuri Bugay, 3 Mahnitohorskyi Lane, 02094, Kyiv, Ukraine. E-mail: ogorodnikov@mail.ru

Yuliia Kovalchuk, Candidate of Technical Sciences, Associate Professor of the Department of Chemistry, Kyiv National University of Construction and Architecture, 31 Povitroflotskyi Ave., 03037, Kyiv, Ukraine. E-mail: juliakovalchuk25@gmail.com 